\title{
Children with type 1 Diabetes Mellitus: access to special immunobiological and child care*
}

\author{
Crianças com diabetes mellitus tipo 1: acesso aos imunobiológicos especiais e à puericultura \\ Niños con diabetes mellitus tipo 1: acceso a los inmunobiológicos especiales y a la puericultura
}

Paula Carolina Bejo Wolkers ${ }^{1}$, Marina Sayuri Yakuwa², Letícia Pancieri'², Clesnan Mendes-Rodrigues ${ }^{1}$, Maria Cândida de Carvalho Furtado ${ }^{2}$, Débora Falleiros de Mello²

How to cite this article:

Wolkers PCB, Yakuwa MS, Pancieri L, Mendes-Rodrigues C, Furtado MCC, Mello DF. Children with type 1 diabetes mellitus: access to special immunobiological and child care. Rev Esc Enferm USP. 2017;51:e03249. DOI: http://dx.doi.org/10.1590/S1980-220X2016049103249

* Extracted from the thesis: "Os cuidados primários à saúde da criança com diabetes mellitus tipo 1 em serviços públicos de saúde: percepção de mães e cuidadores", Escola de Enfermagem de Ribeirão Preto, Universidade de São Paulo, 2014.

${ }^{1}$ Universidade Federal de Uberlândia, Uberlândia, MG, Brazil.

${ }^{2}$ Universidade de São Paulo, Escola de Enfermagem de Ribeirão Preto, Ribeirão Preto, SP, Brazil.

\section{ABSTRACT}

Objectives: Identifying the use of child care situations, the vaccination situation and the reasons for non-vaccination, and characterizing whether mothers/guardians demonstrate notions about the right to special vaccines for children with type 1 Diabetes Mellitus. Method: A descriptive, cross-sectional study with analysis of quantitative data based on interviews with mothers/guardians, particularly regarding access to childcare and vaccination against influenza and pneumococcal 23-valent (PPSV). Results: 47 mothers/ guardians participated in the study. The participants reported using more specialized services to follow child health, and only a few used the child care of the basic health care regularly. There were incomplete vaccination schedules, delayed annual follow-ups, missing vaccination cards at the consultations, misinformation about the special character of the vaccination, as well as emphasis on the need of presenting a specific form to obtain the vaccination, resulting in discontinuation of health actions and missed opportunities for vaccination. Conclusion: Fragilities in child care and immunization actions require an increase of primary health care and of the care network, based on knowledge and the right to health in order to expand the evidence-based practice, access and comprehensiveness.

\section{DESCRIPTORS}

Child; Diabetes Mellitus; Vaccination; Child Care; Pediatric Nursing; Primary Health Care. 


\section{INTRODUCTION}

Type 1 Diabetes Mellitus (T1DM), previously known as juvenile and/or insulin-dependent diabetes, represents a very frequent chronic health condition in the child population ${ }^{(1)}$.

In world terms, the occurrence of T1DM in children is expressive and its incidence has been increasing around 3\% per year ${ }^{(2-6)}$. This disease can present long-term complications, and is the cause of high morbidity and mortality with impacts on the quality of life and increasing healthcare costs requiring interdisciplinary interventions, comprehensive care, health education, monitoring/follow-up checkups, surveillance, and rational and efficient use of available technologies ${ }^{(7-8)}$.

Families with children affected by T1DM face daily challenges in maintaining adequate blood glucose levels, preventing complications, continuing treatment and increasing knowledge about disease management ${ }^{(5-6)}$. Access to services and integration of health care are also fundamental and constitute challenges for organizing health care for these children, being common situations in the Brazilian reality ${ }^{(5-6,9)}$.

In Primary Health Care (PHC), basic actions for the child focus on monitoring growth and development, immunization, breastfeeding, healthy eating, accident prevention and attention to diseases prevalent during childhood, taking into consideration that family participation and partnership with health and community services are essential ${ }^{(10-11)}$. $\mathrm{PHC}$ is at the central and structuring axis of health systems, seeking effective and articulated work for care of infectious, acute and chronic conditions ${ }^{(12)}$, and its role is to coordinate the Health Care Network $(\mathrm{HCN})^{(13)}$. Thus, HCNs constitute polyarchical organizations of health service groups connected by a single mission of cooperative and interdependent action, offering continuous and comprehensive care, and which are currently in the implementation process in Brazil. Child health care in the context of the Brazilian PHC presents weaknesses and ineffective articulation between the care attention points of the current health system ${ }^{(3-4)}$, demonstrating that there is no effective $\mathrm{PHC}$ coordination and that all the possibilities for child health care and its effectiveness are not being explored ${ }^{(4)}$.

Follow-up monitoring of the health of children affected by T1DM is of paramount importance, taking into account the need for regular evaluations and support to children and their families ${ }^{(14)}$. Precarious access of children with T1DM to specialized health services is linked to an increase in the number of hospitalizations and also to the onset of serious complications such as diabetic ketoacidosis and severe hypoglycemia $^{(15-16)}$, requiring regular health monitoring/checkups.

Another important aspect to be considered regarding the health of these children is vaccination, which should be seen as an important indicator of child health improvement and one of the effective measures against a considerable proportion of diseases, as well as due to its effectiveness, cost-effectiveness and impact on infant mortality ${ }^{(11,17-18)}$. Children with chronic diseases, and especially those with T1DM, are entitled to the vaccines of the National Immunization Program (PNI - Programa Nacional de Imunização) available to all Brazilians, and to Special Immunobiological drugs available at the Special Immunobiological Reference Centers (CRIEs
- Centros de Referência de Imunobiológicos Especiais ${ }^{(19)}$. In this context, children with T1DM are entitled to annual influenza and 23-valent pneumococcal (polysaccharide) vaccination at any stage of life, respecting the recommended minimum age ${ }^{(19)}$. Children with T1DM represent a group of patients at risk for influenza and invasive pneumococcal diseases, and therefore receiving adequate inoculation is a priority ${ }^{(20-21)}$.

Faced with gaps in care and the fragmentation of health actions with possible losses in the provision of care in the context of PHC, it is relevant to question how the vaccination coverage and regularity in the care of children with T1DM are. Thus, the present study aimed at identifying the utilization of child care, the vaccination situation and the reasons for non-vaccination, and characterizing whether mothers/guardians demonstrate notions about the right to special vaccines for children with T1DM.

\section{METHOD}

A descriptive, cross-sectional study with quantitative data analysis based on interviews with mothers/guardians of children with T1DM, particularly regarding access to child care and immunization with pneumococcal vaccines and against influenza.

The study was carried out in the city of Uberlândia, Minas Gerais state, at the outpatient clinic of the Municipal Center for Diabetes Care (CMAD - Centro Municipal de Atenção ao Diabético), linked to the Municipal Health Department of Uberlândia, and the Pediatric Outpatient Clinic of the Hospital de Clinicas (APedUFU) of the Universidade Federal de Uberlândia-MG.

Inclusion criteria were: mothers or guardian of children aged between 0 and 11 years, 11 months and 29 days, counted from the date of the beginning of data collection, whose children had a medical diagnosis of T1DM, and performed follow-up consultations at the specialized outpatient clinics for children with DM by Unified Health System (SUS - Sistema Unico de Saúde) in the city of Uberlândia-MG, residents of Uberlândia-MG, and who were being cared for by the mother or legal guardian of the child. Exclusion criteria were: follow-up performed at private health services; residing in other municipalities; those not able to be contacted after three attempts by telephone and/or home visits.

Based on data from the CMAD and the APedUF, it was possible to estimate the number of children under 12 years of age diagnosed with T1DM, enrolled in the mentioned health services and residing in Uberlândia-MG.

According to the registered medical data collected in July 2013, information on 80 children were obtained, including their name, parents name, address, telephone number, date of the last visit/consultation and the date of the next visit/ consultation to that service. Of the 80 children, 24 (30\%) were in the private service and enrolled in the public service only for receiving medication and materials made available for free to children with T1DM. Thus, only 56 children met the inclusion criteria. Among them, five mothers did not agree to participate in the study and four were not found after three attempts, totaling 47 mothers/guardians who participated in this study. 
Data collection occurred from July 2013 to February 2014. The semi-structured interviews were carried out in the waiting rooms of the outpatient clinics on the day of the consultations with the endocrinologist, with clarifications regarding the study objectives and optional participation conducted by the first author of this article. The interview was guided by a script prepared by the researchers to obtain sociodemographic data and information on utilization of child care and vaccination. The script covered the following aspects: age and gender of the child, time for determining the diagnosis, use of health services, professionals who provided information on vaccinations, the use of a specific form for requesting special vaccines and understanding vaccination as a right in the context of health.

Immunization was verified with the vaccination card, and when the mother/guardian was not in possession of the card, their report was considered. PNI vaccines and those indicated by the CRIE were checked, whether the children received all of them, whether they were received at the recommended age, whether there were any delays or vaccinations that were missing from the card and that could have been administered, considering the diagnosis date of T1DM. Some reasons for non-vaccination and delay were also collected in the interview, as well as whether professionals from specialized outpatient clinics and basic care provided any recommendation regarding the delay.

Statistical analyzes were performed to verify the state dependence of the vaccination schedule with the diagnosis time (categorized as up to 24 months and over 24 months), and the child's age (with categories ranging from 0 to 119 months and from 120 to 144 months), using the $\mathrm{G}$ test of independence. Diagnosis time categorization was based on the lowest median and mean of the groups with regularity or not in the vaccination schedule. Age categorization followed the criterion of creating two groups with approximate numbers. BioEstat 5.0 statistical software was used for all analyzes. The level of significance assumed for the tests was $5 \%$.

The present study was approved by the Ethics Committee in Research with the opinion number 405818 and CAAE 09258813800005393, and it followed the recommendations of Resolution 466/12 of the National Health Council.

\section{RESULTS}

Of the 47 participants in the study, 38 were mothers and nine were others (father or grandparent), ranging in age from 18 to 61 years. In relation to the children, 25 of them were male and 22 were female; regarding the age group, six were younger than 5 years of age, 18 were between 6 and 9 years of age, and 23 were between 10 and 11 years 11 months and 29 days of age. The mean time to reach the T1DM diagnosis definition in children was 3 years and 7 months.

Of the 47 mothers/guardians interviewed, all mentioned that children with T1DM have regular health checkups in the specialized outpatient clinic. Of the total number of participants in the study, 35 (74.5\%) did not regularly use the child care service of the Primary Care Units (PCU), and follow-up of the child's health was only carried out in the specialized endocrine/pediatric outpatient clinic. In the present study, 12 (25.5\%) mothers reported using both the child care and specialized follow-up services.

Regarding the monitoring of children and the definition of the T1DM diagnosis, it was noticed that the longer elapsed time for this definition, the smaller the regularity in child care in the PCUs, as shown in Table 1.

Table 1 - Follow-up of children with T1DM in child care, according to the diagnosis time - Uberlândia, Minas Gerais, Brazil, 2014.

\begin{tabular}{lcccc}
\hline $\begin{array}{c}\text { Follow-up of } \\
\text { T1DM children }\end{array}$ & $\begin{array}{c}\text { Diagnosis } \\
\mathbf{2} \text { 24 months }\end{array}$ & $\begin{array}{c}\text { Diagnosis } \\
\mathbf{2 4} \text { months }\end{array}$ & Total & $\begin{array}{c}\text { P value } \\
\text { (G Test) }\end{array}$ \\
\hline Regular child care & 9 & 3 & 12 & $\mathrm{G}=4.51$ \\
Irregular child care & 12 & 23 & 35 & $\mathrm{p}=0.03$ \\
\hline Total & 21 & 26 & 47 & \\
\hline
\end{tabular}

The children's age did not seem to be significantly related to regularity in the child care monitoring. It should be mentioned that this fact can be explained by the small sample number.

Vaccination status of the investigated children was appropriate for their age regarding the routine vaccine schedule. Regarding immunization with 23-valent pneumococcal and influenza vaccines, nine (19.2\%) were up-to-date regarding these vaccines and $38(80.8 \%)$ were incomplete. Of these incomplete schedules, 11 (28.9\%) did not receive both vaccines; six (15.8\%) received both, but the reinforcements were incomplete; 11 (28.9\%) received only the influenza vaccine and their respective boosters annually; and 10 (26.4\%) received the influenza vaccine, but the annual boosters were incomplete. It is important to emphasize that 31 (65.9\%) mothers/guardians did not bring the vaccination card to the specialist outpatient clinic consultation, and therefore most of the information obtained was by oral report of the participants.

Among the reasons pointed out by the participants for not bringing the vaccination card, $19(40.4 \%)$ reported that they did not bring it because the card was not requested, 26 $(55.4 \%)$ mention they usually forget, and two (4.2\%) because they understand that the vaccination card is complete.

Regarding the offer of information about these vaccines, $12(25.5 \%)$ participants reported that they were obtained based on guidelines from the physicians of the endocrine/ pediatric outpatient clinic, six (12.7\%) from the media, five (10.6\%) from the primary care or family health strategy physician, five $(10.6 \%)$ researched the subject, three $(6.4 \%)$ from the Nursing unit of the basic health unit or family health strategy, three (6.4\%) from their relatives, three (6.4\%) from friends and neighbors and one (2.2\%) knew about it from another health professional. It should be noted that nine (19.2\%) were not aware about the two special vaccines for children with T1DM and only became aware during the present study.

In relation to the professional who requested the vaccination, 22 (46.8\%) of the participants reported that no one requested it, 15 (31.9\%) answered that it was the physician of the endocrine/pediatric outpatient clinic, seven (14.9\%) that it was the physician of the primary unit or of the family 
health strategy, one (2.2\%) that it was the nursing unit of the basic unit or family health strategy, and two (4.2\%) were other health professionals.

Regarding the request for vaccine boosters, eight (88.9\%) of the patients who had the vaccines up-to-date reported that a new form is required for the booster vaccine application, meaning that the service does not provide reinforcement of the vaccination without a written form request by a health professional. In general for the 38 remaining children who received one or both vaccines at any moment, 30 (78.9\%) participants reported that a new form was needed for the boosters. However, six (15.9\%) participants reported that the vaccine service provided the reinforcements at some point without a new request, and two participants (5.3\%) did not remember. In this aspect, those who never received the two vaccines were excluded.

T1DM diagnostic time is information that may influence the child's vaccination schedule. Children with more than 24 months of T1DM diagnosis presented better vaccine situations regarding the vaccines recommended by CRIE, according to data from Table 2 .

Table 2 - Vaccination schedule for influenza and pneumococcal 23-valent in children with T1DM, according to diagnosis time Uberlândia, Minas Gerais, Brazil, 2014.

\begin{tabular}{cccccccc}
\hline Diagnosis time & A $^{*}$ & $\mathbf{B}^{* *}$ & $\mathrm{C}^{* * *}$ & $\mathrm{D}^{* * * *}$ & $\mathrm{E}^{* * * * *}$ & Total & $\begin{array}{c}\text { P value } \\
\text { (G test) }\end{array}$ \\
\hline$<24$ months & 4 & 9 & 4 & 4 & & $\mathbf{2 1}$ & $\mathrm{G}=13.05$ \\
$>24$ months & 5 & 2 & 7 & 6 & 6 & $\mathbf{2 6}$ & $\mathrm{P}=0.01$ \\
\hline
\end{tabular}

*Complete vaccinations, ${ }^{* *}$ Incomplete vaccinations (none of the two special vaccines doses), ${ }^{* * *}$ Complete Influenza vaccine and its complete boosters, ${ }^{* * * *}$ Complete Influenza vaccine and its incomplete boosters, ${ }^{* * * * *}$ Complete vaccines and their incomplete boosters.

As the vaccination schedule depended on the diagnosis time and it was not identified which schedule differed between the times, each vaccine schedule was compared for the two diagnostic times and verified by the Binomial test for proportions. Through this test it was possible to identify the statistical difference in the variable "totally incomplete vaccination schedule" $(\mathrm{P}=0.0046)$, meaning that the longer the time of the diagnosis and the follow-up in the specialized outpatient clinics, the less incomplete schedules were found.

Age and follow-up in child care in PCUs were not related to the complete CRIE vaccination scheme. It should be noted that no children only received the pneumo 23 vaccine.

Being aware of the rights of children with T1DM to receive 23-valent pneumococcal and influenza vaccines was mentioned by $21(44.7 \%)$ study participants, while 17 (36.1\%) were only aware of one of the vaccines. Some of the participants $(9-19.2 \%)$ were not aware that access to a special vaccine was also the children's right, and reported having no knowledge about it.

\section{DISCUSSION}

The present study shows aspects of longitudinality at two points of health care (basic care and specialized outpatient clinic), with emphasis on the use of health actions for child care and vaccination follow-up for children with
T1DM from the perspective of mothers/guardians. The aspects portrayed suggest that the insertion and the link with specialized services can make it seem that the follow-up at the primary care is not identified as an absolute necessity. Likewise, they suggest that participants believe that followup at specialized services is enough.

Consistent with other investigations ${ }^{(12,22)}$, the information obtained (in this study) shows similarities regarding the fragmentation of actions in health monitoring. Health service fragmentation has been identified and related to the following causes ${ }^{(22)}$ : institutional segmentation of the health system; decentralization of health services; programs predominantly focused on diseases, risks and populations (vertical programs) that are not integrated into the health system; exceptional situations where vertical programs have a precise indication in countries in fragile situations with the need to control epidemics and major health emergencies, or the need to provide services to special populations; separating extreme public health services for people; care model focused on the disease, care in acute episodes and hospital care; gaps in health and intersectoral management; problems with the quantity, quality and distribution of resources; deficiency in the definition of roles, skill level, hiring gaps and wages of health personnel; multiplicity of ways of paying institutions and payment mechanisms for services; conduct of service providers which are contrary to the concept of integration; legal and administrative barriers; and promotion of vertical international programs. Therefore, such factors challenge the responsiveness of existing services, and it should be noted that the occurrence of chronic diseases requires greater integration between primary and specialized care, aspects that are also linked to the results of the present study.

The results of low utilization of child care, incomplete vaccination schedules and little information on the special character of vaccination in T1DM children investigated herein suggest weaknesses in access to care and guidelines. These results raise questions related to the quality of care and to the articulation between primary and specialized care, as already pointed out in one study ${ }^{(12)}$ which discusses that actions and services need to be strengthened in the context of PHC in order to improve access, quality and cost reduction. Articulation between services reduces costs, without adverse effects on quality or health outcomes ${ }^{(12)}$.

$\mathrm{HCN}$ s can be a solution as they offer approaches that improve the continuity of health actions and coordination between services; however, more studies are needed to identify network outcomes and challenges ${ }^{(23)}$. When managing a chronic disease such as T1DM in children, planning, monitoring and adequacy of health monitoring actions in the network can bring forth more benefits to the longitudinality of care based on the context of children's needs. In this sense, the results of the present study show that regularity of follow-ups in child care in basic health care and in specialized outpatient clinics need to be integrated in order to ensure more access and full care. Thus, local health systems, as in the municipality under study, may seek to fulfill the following essential functions in the PHC from the $\mathrm{HCN}$ perspective: resoluteness to meet $85 \%$ of the most common health 
problems; coordination of flows and counter-flows of people, products and information in the networks; and accountability for the health of the population ${ }^{(12)}$. Moreover, in the organization of $\mathrm{HCN}$, having the $\mathrm{PHC}$ as the coordinator of the care and ordering of the network can present itself as a mechanism to overcome systemic fragmentation, being more effective both in terms of organization and capacity to deal with the current challenges of the socioeconomic, demographic, epidemiological and health scenario ${ }^{(22)}$.

In the present study, a small portion of the children with T1DM had the special vaccines (23-valent pneumococcal and influenza) in a complete up-to-date schedule. Still, they presented delayed annual reinforcements, the vaccination cards were missing at the visits/consultations, there was misinformation about the special character of the vaccination, as well as the emphasis on the need to present a specific form to obtain the vaccination. The results indicate a discontinuity of health actions, particularly in the vaccination practice in cases of children with T1DM. Such results bring worrying aspects, since children with chronic diseases also need to be considered in immunization strategies, as this condition predisposes them to infections and complications, and highlights the importance of the role of PHC in constantly guiding families on the protection of children's health. Similar aspects were pointed out in other studies, highlighting the importance of updating vaccine schedules in which a lack of information was the main reason for non-vaccination ${ }^{(24)}$, delays in vaccinating children with chronic diseases related to a concurrent acute event or lack of information from parents $^{(20)}$, and some reasons for refusal were related to health system problems, fears of adverse reactions, concerns related to chronic diseases and the immune system ${ }^{(25)}$.

In the present investigation, mothers/guardians reported that they became aware of the right to the vaccines outside of the health services context. In the analyzed health services, the specialized clinic provided the most information. Another aspect to emphasize is that in most cases, vaccine services request a new form for each vaccine booster, which can be a shortcoming and create a strong obstacle to keep vaccinations up-to-date as a result of the difficulty of getting the child's medical reports regarding their health and illness state. In the case of T1DM, which is a disease that has no cure, new forms informing that the patient has the disease should not be required for the vaccine boosters. These aspects suggest fragile participation of basic care and nursing in general regarding vaccination of children with a chronic disease.

Studies ${ }^{(20,24,26)}$ on vaccination in children with chronic diseases point to the importance of being aware of the missed opportunities of vaccination. Children seen in the vaccination ward are not identified by the nature of their chronic illness, and a solution would be crossing information from clinical records with those of the vaccination system $^{(26)}$, rigorous monitoring of routine vaccinations and other recommended vaccines, information regarding false contraindications ${ }^{(21)}$, and advances in strategies to improve adherence to the vaccination schedule in special programs targeted at vulnerable patients ${ }^{(20,24)}$.
Vaccination is considered a routine action in health services, particularly in the context of PHC, with great influence on the overall health conditions of the child as it represents an expressive technological advance in health in recent decades, and it is a good cost-effective procedure in the health sector. The more vaccination is integrated into child care and their growth and development process, the more successful it will be, also contributing to broaden the understanding of families about this health action ${ }^{(27)}$.

The results specified here are relevant to the discussions on health protection and for preventing children's illnesses with T1DM, as well as the reorganization, access and quality of actions and health services, particularly in the case of chronic health conditions during childhood, improving access to immunobiological devices available in the CRIEs, and an overall broader offer (of care) according to children's health needs. The results also indicate the importance of the health professional's role in clarifying information, in changing attitudes and beliefs and in the understanding concerning rights, with repercussions and openness to new investigations.

\section{CONCLUSION}

The present study pointed to weaknesses in child care and vaccination actions in children with T1DM, highlighting the low vaccination coverage of the vaccines provided by the CRIEs and gaps in the follow-up regularity in primary health care, especially in children with a longer T1DM diagnosis time.

Despite the development of various vaccines and immunoglobulins and government strategies for immunization and health monitoring of children with chronic conditions, families still face situations of non-access, discontinuity of health actions and missed opportunities for vaccination and early childhood health care. Changes in such situations are related to the advancement of nursing practice, as well as to the dimensions of teaching and research in nursing which can greatly contribute to advancing comprehensive care actions in children's health.

Strengthening PHC and networked care based on knowledge and health advocacy will contribute to reducing missed immunization opportunities and fragile actions in comprehensive care. It is up to health professionals to focus on all of these issues, indicating gaps for comprehensive health care which implies in greater protagonism and accountability, as well as the need to rethink and rediscuss actions and public policies, network care management, $\mathrm{PHC}$ resolution, universal access and coverage in health in order to impact on quality of life and reduce children's morbidity and mortality.

The present investigation presents limitations regarding sample size linked to the exclusive monitoring of the public health service of the municipality in question, which prevents its expansion; and the non-direct verification of the vaccination status in the child's health card in some cases, in which the mother's reports were taken into account. It is important that more studies address this issue, highlighting vulnerable groups and their chronic health conditions. 
RESUMO

Objetivos: Identificar a utilização da puericultura, a situação vacinal e os motivos da não vacinação, e caracterizar se as mães/responsáveis apresentavam noções sobre o direito às vacinas especiais de crianças com diabetes mellitus tipo 1. Método: Estudo descritivo, transversal, com análise de dados quantitativos, a partir de entrevistas com mães/responsáveis, particularmente quanto ao acesso à puericultura e à vacinação contra influenza e pneumocócica 23-valente. Resultados: Participaram da pesquisa 47 mães/responsáveis. Os participantes afirmam que utilizam mais os serviços especializados para acompanhamento da saúde da criança, poucos utilizam a puericultura com regularidade na atenção básica à saúde. Há esquemas vacinais incompletos, reforços anuais atrasados, ausência do cartão de vacinação nos atendimentos, desinformação sobre o caráter especial da vacinação, bem como a ênfase na necessidade de apresentar formulário específico para obter a vacinação. Há descontinuidade das ações de saúde e oportunidades perdidas em vacinação. Conclusão: Fragilidades das ações de puericultura e de vacinação requerem incremento da atenção primária à saúde e do cuidado em rede, apoiado em conhecimentos e no direito à saúde para expandir a prática avançada em evidências, o acesso e a integralidade.

\section{DESCRITORES}

Criança; Diabetes Mellitus; Vacinação; Cuidado da Criança; Enfermagem Pediátrica; Atenção Primária à Saúde.

\section{RESUMEN}

Objetivos: Identificar la utilización de la puericultura, la situación vacunal y los motivos de la no vacunación, y caracterizar si las madres/ responsables presentaban nociones acerca del derecho a las vacunas especiales de niños con diabetes mellitus tipo 1. Método: Estudio descriptivo, transversal, con análisis de datos cuantitativos, a partir de entrevistas con madres/responsables, particularmente en cuanto al acceso a la puericultura y la vacunación contra influenza y neumocócica 23-valente. Resultados: Participaron en la investigación 47 madres/responsables. Los participantes afirman que utilizan más los servicios especializados para acompañamiento de la salud del niño, pocos utilizan la puericultura con regularidad en la atención básica de salud. Hay esquemas vacunales incompletos, refuerzos anuales retrasados, ausencia de la tarjeta de vacunación en las atenciones, desinformación sobre el carácter especial de la vacunación, así como el énfasis en la necesidad de presentar formulario específico para obtener la vacunación. Existe discontinuidad de las acciones sanitarias y oportunidades perdidas en vacunación. Conclusión: Fragilidades de las acciones de puericultura y de vacunación requieren incremento de la atención primaria de salud y del cuidado en red, apoyado en conocimientos y el derecho a la salud para expandir la práctica avanzada en evidencias, el acceso y la integralidad.

\section{DESCRIPTORES}

Niño; Diabetes Mellitus; Vacunación; Cuidado del Niño; Enfermería Pediátrica; Atención Primaria de Salud.

\section{REFERENCES}

1. Geraldo RT, Ferreira LV, Leite CCA, Ezequiel DGA, Moutinho BD, Silva EA, et al. Diabetes mellitus tipo 1 de curta duração e suas implicações sobre a qualidade de vida. Rev Bras Med. 2015;72(10):448-53.

2. Rubin O, Azzolin K, Muller S. Adesão ao tratamento de Diabetes Mellitus tipo 1 atendidos em um programa especializado em Porto Alegre. Medicina. 2011;44(1):367-76.

3. Lawrence JM, Imperatore G, Dabelea D, Mayer-Davis EJ, Linder B, Saydah S, et al. Trends in incidence of type 1 diabetes among nonHispanic White youth in the U.S., 2002-2009. Diabetes. 2014;63(11):3938-45.

4. Fazeli Farsani S, Souverein PC, Van der Vorst MMJ, Knibbe CA, Herings RM, Boer A, et al. Increasing trends in the incidence and prevalence rates of type 1 diabetes among children and adolescents in the Netherlands. Pediatr Diabetes. 2016;17(1):44-52.

5. Cameron FJ, Scratch SE, Nadebaum C, Northam EA, Koves I, Jennings J, et al. Neurological consequences of diabetic ketoacidosis at initial presentation of type 1 diabetes in a prospective cohort study of children. Diabetes Care. 2014;37(6):1554-62.

6. Maahs DM, Hermann JM, DuBose SN, Miller KM, Heidtmann B, DiMeglio LA, et al. Contrasting the clinical care and outcomes of 2,622 children with type 1diabetes less than 6 years of age in the United States T1D Exchange and German/Austrian DVP registries. Diabetologia. 2014;57(8):1578-85.

7. Cobas RA, Ferraz MB, Matheus ASM, Tannus LR, Negrato CA, Araujo AL, et al. The cost of type 1 diabetes: a nationwide multicentre study in Brazil. Bull World Health Organ. 2013;91(6):434-40.

8. Williens D, Cripps R, Wilson A, Wolff K. Interdisciplinary team care for diabetic patients by primary care physicians, advanced practice nurses, and clinical pharmacists. Clin Diabetes. 2011;29(2):60-8.

9. Malaquias MST, Marques CDC, Faria ACP, Pupulim JSL, Marcon SS, Higarashi IH. A criança e o adolescente com diabetes mellitus tipo 1: desdobrar do cuidado familiar. Cogitare Enferm. 2016;21(1):1-7.

10. Victora GC, Aquino EMMLL, Leal MC, Monteiro CA, Barros FC, Szwarcwald CL. Maternal and child health in Brazil: progress and challenges. Lancet. 2011;377(9780):1863-76.

11. Fundo das Nações Unidas para a Infância (UNICEF). Guia dos direitos da gestante e do bebê. São Paulo: Globo; 2011.

12. Mendes EV. O cuidado das condições crônicas na atenção primária à saúde: o imperativo da consolidação da estratégia da saúde da família. Brasília: Organização Pan- Americana da Saúde; 2012.

13. Mendes EV. As redes de atenção à saúde. Brasília: Organização Pan-Americana da Saúde; 2011.

14. Martins EMCS, Ataíde MBC, Silva DMA, Frota MA. Vivência de mães no cuidado à criança diabética tipo 1. Rev Rene. 2013;14(1):42-9.

15. Naranjo D, Mulvaney S, McGrath M, Garnero T, Hood K. Predictors of Self-Management in pediatric type 1 diabetes: individual, family, systemic, and technologic influences. Curr Diab Rep. 2014;14(11):544.

16. American Diabetes Association. Children and adolescents. Diabetes Care. 2015;38(1):70-6. 
17. Domingues CMAS, Teixeira MAS, Carvalho SMD. National immunization program: vaccination, compliance and pharmacovigilance. Rev Inst Med Trop. 2012;54(18):22-7.

18. Lessa SC, Schramm FR. Proteção individual versus proteção coletiva: análise bioética do programa nacional de vacinação infantil em massa. Ciênc Saúde Colitiva. 2015;20(1):115-24.

19. Brasil. Ministério da Saúde; Secretaria de Vigilância em Saúde, Departamento de Vigilância das Doenças Transmissíveis. Manual dos Centros de Referência para imunobiológicos especiais. 4a ed. Brasília: MS; 2014.

20. Pandolfi E, Carolini E, Marino MG, Ciofi degli Atti ML, Gesualdo F, Romano M, et al. Immunization coverage and timeliness of vaccination in Italian children with chronic diseases. Vaccine. 2012;30(34):5172-8.

21. Çamurdan $M O$, Çamurdan $A D$, Beyazova $U$, Bideci $A$. The rate of seasonal influenza vaccination in diabetic children, the effect of recommendation and the factors influencing the acceptance of recommendation: an interventional study. Balkan Med J. 2012;29(4):434-9.

22. Organização Pan-Americana da Saúde; Ministério da Saúde. Inovação nos sistemas logísticos: resultados do laboratório de inovação sobre redes integradas de atenção à saúde baseadas na APS. Brasília: OPAS; 2011.

23. Willis CD, Riley BL, Herbert CP, Best A. Networks to strengthen health systems for chronic disease prevention. Am J Public Health. 2013;103(11):e39-48.

24. Barbieri CLA, Dias C, Moraes JC, Veras MASM, Santos MAN, Petlik MEl. Cobertura vacinal em um serviço filantrópico de atenção primária à saúde do município de São Paulo, Estado de São Paulo, Brasil, em 2010. Epidemiol Serv Saúde, 2013;22(1):129-39.

25. Luthy KE, Beckstrand RL, Callister LC. Reasons parents exempt children from receiving immunizations. J Sch Nurs. 2012;28(2):153-60.

26. Dombkowski KJ, Costello L, Dong S, Clark SJ. Using administrative claims to identify children with chronic conditions in a statewide immunization registry. Am J Manag Care. 2014;20(5):e166-74.

27. Figueiredo GLA, Pina JC, Tonete VLP, Lima RAG, Mello DF. Experiences of families in the immunization of Brazilian children under two years old. Rev Latino Am Enfermagem. 2011;19(3):598-605. 